\title{
Cross-Border Couriers \\ as Symbols of Regional Grievance?
}

\author{
The Malayitsha Remittance System in Matabeleland, Zimbabwe*
}

\author{
Tinashe Nyamunda \\ Centre for Africa Studies, University of the Free State, South Africa \\ nyamundat@gmail.com
}

\begin{abstract}
This article explores the history and experiences of cross-border couriers/transporters known as omalayitsha, who remit money and commodities across the border between South Africa and Zimbabwe. Based on interviews with omalayitsha operators, customers and state officials in Matabeleland, it furthers debates over remittances in several ways. First, the focus on couriers and transport operators themselves (rather than on the migrants who are their customers) provides a novel perspective, as the remittance literature tends to overlook these businesses. The article scrutinises couriers' modus operandi and business relationships with clients, state officials, collaborators and rivals, exploring moral economies, and the entanglement of irregular modes of operation with state authority. The three-fold typology of large, medium and smallscale omalayitsha shows significant variation in relations with the Zimbabwean and South African regulatory authorities. Second, the article emphasises the importance of regional histories and spatial variation, criticising the tendency for debates over remittances to depend on national scale data and ignore geographical differences. The development of the malayitsha remittance system is widely upheld within Matabeleland as a symptom of the region's marginalisation and displacement, linked to the aftermath of the episode of state violence in the 1980s known as Gukurahundi. I argue that in
\end{abstract}

* This research was funded through ESRC grant RES 00022 3795. I must thank JoAnn McGregor for her financial, moral and academic support. I am also grateful for feedback received in the economic history seminar series, University of Zimbabwe as well as the British Zimbabwe Society research day, St Antony's College, Oxford. I wish to express my gratitude to Professor Ian Phimister for his continuous encouragement and funding that enabled the presentation of the paper at the Southern African Historical Association Conference, Botswana, June 2013. All errors, of course, remain my own.

(C) TINASHE NYAMUNDA, 2014 | DOI: 10.1163/18725465-00701003

This is an open access article distributed under the terms of the Creative Commons 
Matateleland, the figure of the malayitsha is upheld as an icon of regional neglect and enforced cross-border engagement.

\section{Keywords}

malayitsha remittance system - courier businesses - informality and state regulations - identity and belonging

\section{Résumé}

Cet article explore l'histoire et les expériences des livreurs/transporteurs transfrontaliers aussi connus sous le nom d'omalayitsha, qui transportent l'argent et les biens de part et d'autre de la frontière qui sépare l'Afrique du Sud du Zimbabwé. Sur base d'entretiens avec des acteurs, des opérateurs, des clients et des représentants officiels du système d'omalayitsha au Matabeleland, cet article contribue au débat entourant les rémittences de plusieurs manières. Tout d' abord, l' accent sur les livreurs et les transporteurs eux-mêmes (plutôt que sur les migrants qui sont leurs clients) apporte une perspective nouvelle tant il est vrai que la littérature sur les rémittences tend à négliger cet aspect. L'article examine les modus operandi des livreurs et les relations commerciales avec les clients, les représentants officiels, les collaborateurs et les concurrents, explorant les économies morales et les imbrications des modes d'opération avec les autorités de l'Etat. Cette triple typologie des omalayitsha à une grande, moyenne et petite échelle montre les variations importantes des relations entre les autorités de régulation zimbabwéenne et sud-africaines. Ensuite, l'article met l' accent sur l' importance des histoires régionales et de la variation spatiale, en critiquant la tendance des débats sur les rémittences à se concentrer sur les données nationales au détriment des différences géographiques. Le développement du système de rémittences malayitsha est largement considéré au Matabeleland comme un symptôme de la marginalisation et de la relégation qu' a connue cette région, à la suite de l'épisode de la répression par le gouvernement dans les années 80 connu sous le nom de Gukurahundi. Je défends l'idée selon laquelle au Matateleland, la personne du malayitsha symbolise la négligence dont souffre la région et l' engagement renforcé de part et d' autre de la frontière.

\section{Mots-clés}

systèmes des rémittences malayitsha-commerce des livreurs - régulations informelles et étatiques - identité et appartenance 


\section{Introduction}

The article examines the rise of informal transport and courier businesses in Matabeleland known as omalayitsha, ${ }^{1}$ which operate across the Zimbabwe/ South Africa border. The name malayitsha is a SiNdebele term which means 'the one who carries a heavy load'. The omalayitsha operators consist of private businesses of a range of scales, from small, often unregistered couriers using pick-up trucks or mini buses to ferry money and other goods across the border from South Africa and Botswana, to large consortia and registered transport companies. Some make use of established depots where their vehicles bring cargo for storage and collection, but a significant part of the business also involves door-to-door deliveries across the region and beyond. Cross-border business boomed as the Zimbabwe crisis deepened from the late 1990s. But as I argue here, omalayitsha also have a longer history, which is connected to prior episodes of emigration, particularly to the aftermath of the state massacres of the 1980s, known as Gukurahundi (Alexander et al. 2000; Phimister 2008; CCJP 1999).

This study of the omalayitsha contributes to broader debates over remittances in several ways. First, it focuses on a neglected dimension of remittance economies - namely the perspectives and practices of the courier businesses themselves - which is largely absent from existing literature. My analysis involves developing a three-fold typology of small, medium and large-scale operators, who have varied relationships with the Zimbabwean and South African states. The article analyses informality in the malayitsha system in a manner that does not assume a world beyond the gaze of the state. Like Roitman, I explore the close intersections between state regulations and 'fiscal disobedience' (Roitman 2005). Informal economies are often misleadingly referred to as operating 'parallel' to the state (Bracking and Sachikonye 2010; Mawowa and Matongo 2010), which does not sufficiently emphasise their mutual entanglement, and in the case of omalayitsha, civil servants are involved in facilitation, while central and local state regulations against unregistered operators are not effectively enforced. Unlike Roitman's (2005) study of the Chad Basin, which focuses on popular protests over the state's failure to protect regulated traders from their unregulated competitors, my focus here is on both registered couriers and their illegal rivals. The formal/informal distinction is important insofar as it is used in popular discourse and can shed light on

1 Malaitsha is singular whereas omalaitsha is plural. 
differential degrees of compliance with, and relationships to, state regulatory bureaucracy, but is also misleading in other ways, as both registered and unregistered categories of operator allegedly engage in irregular practices. Moreover, in the case of the omalayitsha, both types of courier articulate a shared sense of regional neglect and ethnic discrimination.

Second, the article contributes to a broader literature and understanding of remittances by emphasising the importance of a regional dimension to remittance economies, and offering a critique of studies that use only a national scale (such as Vargas-Lundius et al. 2008; Mutowo 2009). The history of the malayitsha remittance system disrupts timelines of displacement to South Africa that began in the late 199os with Zimbabwe's recent crisis, as operators trace their origins to state violence in Matabeleland in the 1980s. This earlier episode of violence produced regional disaffection and fuelled the development of Ndebele nationalism, grounded in reworked histories of nineteenth-century Ndebele power, fondly remembered as Mthwakazi (Ndlovu-Gatsheni 2012; NdlovuGatsheni 2009a, b). Regional grievances were deepened by the national crisis that unfolded from the late 1990s, with Ndebele separatist sentiments giving birth to the Mthwakazi National Party in 2012, which has significant followers in Zimbabwe, South Africa and beyond (Ndlovu-Gatsheni 2012). The history of the development of the malayitsha remittance system is important because of this connection to regional grievances: I argue that the omalayitsh $a$ are upheld within Matabeleland as icons of the region's marginalisation, and to a degree, of resistance to it. The perspectives of the omalayitsha operators who fill the demand for cross-border services between Zimbabwe and South Africa are revealing for the light they shed not only on Matabeleland's disaffection with Zimbabwe, but also on constructions of belonging and cross-border integration.

While the importance of omalayitsha is well established (Bracking and Sachikonye 2010; Crush and Tevera 2010; McGregor and Primorac 2010; Maphosa 2005), no studies have explored the views of those actually running these businesses. Below, I draw on 25 interviews with omalayitsh a and customers in Matabeleland, conducted between July 2011 and December 2012. The large courier interviewees were happy for me to use their actual names, whereas the smaller operators requested anonymity, and I refer to them through pseudonyms. This is because the small businesses were constructed by the police, Ministry of Transport and large registered operators as illegal 'poachers' and 'criminals'.

The article begins with a discussion of Zimbabwe's developing remittance industry, shifting state controls and the growth of unregulated cross-border business, before elaborating the ways in which the omalayitsha have come 
to be seen as a symbol of regional grievance. I then elaborate a three-fold typology of omalayitsha remittance businesses, and historicise recent trends in cross-border trade through the decade of crisis and subsequent period of power-sharing. The remittance and courier transport businesses are intimately connected, as they became the prime means by which migrants within the region sent money and goods home during the crisis.

\section{The Remittance Business, State Regulation and Irregular Practice}

There has been significant scholarly attention to the scale of monetary flows within southern Africa and globally, as it has been recognised that they constitute the largest source of external finance in many developing countries, rising from about us $\$ 30$ billion annually in the early 1990 os to an estimated US $\$ 318$ billion in 2007 (Vargas-Lundius et al. 2008). But these debates lack attention to the details of the businesses that channel remittances, and the perspectives of the entrepreneurs themselves. Studies tend to measure the importance and impact of remittances on a national scale. The literature on remittances in the Zimbabwe crisis is no exception, as it tends to treat remittances as a national issue and pays little attention to regional disparities and specificities (Mutowo 2009; Bracking and Sachikonye 2010; Maphosa 2005). Those who have sought to draw a more differentiated picture have sometimes done so in class terms rather than elaborating regional differences: Bracking and Sachikonye (2010), for example, compare and contrast the differential dependency on remittances of high and medium density urban populations. There is one specific study of remittances in Matabeleland South, by the Solidarity Peace Trust, which usefully highlights the longstanding cross-border integration of this region (SPT 2009). While other border regions of Zimbabwe also have longstanding histories of labour migration and cross-border integration, they lack Matabeleland's history of persecution, and the widely held belief in deliberate regional neglect by the central state.

Many commentators have pointed out that informal routes for remittances predominate in the Zimbabwean context (Maphosa 2005; Bracking and Sachikonye 2010). An IOM survey of Zimbabwe's border posts estimated that US $\$ 3.3$ million in cash and us $\$ 4.4$ million worth of goods were brought into Zimbabwe across the borders through unregulated channels (Mutowo 2009). This reflects popular responses to a range of different state controls on cross-border flows of finance, goods and people, as both Zimbabwean and south African states sought to regulate their borders. Zimbabwe government fiscal controls were an important aspect of the regulatory architecture that remitters and cross- 
border operators had to navigate. From 1997, the economy went into freefall, as the Zimbabwe dollar plummeted $74 \%$ in just 4 hours on 'black Thursday' in November of that year. As the government's capacity to earn foreign exchange dwindled and hyperinflation continued to erode the value of the $\mathrm{Zim} \$$ in the years thereafter, so the government increasingly sought to control all sources of foreign currency, and endeavoured to tap remittance flows. Exchange control measures were tightened and the Reserve Bank sought to monopolise all flows of foreign currency and fixed unrealistically low exchange rates, as well as seizing foreign currency holdings in personal and institutional accounts. In response, street markets in currency emerged to meet the popular demand for exchange outside the banks, and became the central focus of economic life (Jones 2010; Mawowa and Matongo 2010). Governor Gono justified the state policies implicated in deepening the fiscal crisis, arguing "The new ethic that defines the market economy has less to do with work and everything to do with manipulative gambling akin to the workings of a casino" (Gono 2008: 61). State fiscal controls were combined with a series of militarised economic interventions that combined to make legal business impossible: in 2003, Forex bureaux were closed; later in 2007 'Operation Price Controls' sought to fix prices for basic commodities in shops, youth militia seized goods and supermarket shelves were increasingly bare. The border itself was a key site both for state regulation and fiscal disobedience as attempts to control and tax imports and exports gave birth to a flourishing irregular border economy, in which the omalayitsh a were intimately involved.

It was not only fiscal controls and government economic interventions that cross-border businesses had to navigate. Migration and citizenship policies in Zimbabwe and South Africa created a further set of obstacles to cross-border livelihoods and remitting. The Zimbabwe Citizenship Act 2001 and subsequent amendments illegalised dual citizenship and rendered some descendants of migrant workers alien, meaning that they could not apply for passports if they wanted to emigrate (Dorman 2005; Muzondidya 2010, Kriger 2010). The politicised mass urban demolitions of 2005 that destroyed 700,000 Zimbabwean homes and/or livelihoods increased pressure on the Registrar General's (RG) office for passports. But the RG's office failed to handle the rising demand for passports and many people could not afford the official charges themselves, which could amount to the equivalent of US $\$ 400$, let alone the further bribes of $\$ 100$ or so that were commonly paid to officials. ${ }^{2}$ South Africa's restrictive immigration policies compounded the problems of crossing legally as the

2 Interview, Brian, RG office, Harare, 23 August, 2012. 
South African High Commission demanded R200o (ca. \$300) as the application fee before 2009. ${ }^{3}$

South African government policy also sought to discourage unregulated transfer of funds beyond state borders. Official routes for moving money included the large commercial remittance agencies (though Zimbabwean branches of commercial agencies were closed during the peak of the crisis). Bank to bank swift electronic transfers were feasible in principle, but required the sender to provide supporting documents. There is a single discretionary allowance of R1-4 million per calendar year, which individuals can apply for to externalise money, but the average farmworker or vendor cannot dream of remitting such enormous amounts. For most Zimbabweans, official crossborder channels were thus inaccessible. A discussion with Zimbabwean street vendors in Bloemfontein, South Africa showed clearly that the idea of using banks and formal financial institutions to deposit and hold earnings was "not even a consideration". ${ }^{4}$ Even where funds were transferred formally, during the crisis decade, there was no guarantee that the money could be accessed in Zimbabwe.

Since the Zimbabwe dollar was withdrawn in Zimbabwe in 2009, formal remittance options have widened, as global money transfer services are operating in the country again, including Western Union and Moneygram. Other mainstream courier companies such as DHL are also available, and are an option for large businesses and those who can afford the costs. Although these are safe ways to remit, a survey by Send Money Africa found that South African fees were very high, with charges averaging $20.7 \%$ (as opposed to an average across the continent of $12.4 \%$ ), making it the most expensive country from which to send money (Peacock 2013).

These formal means of remitting are thus inconvenient, costly and inaccessible for many Zimbabwean migrants and also impractical for many receivers, particularly those in rural areas. The clandestine status and low income of most migrants explains their preference for omalayitsha. Mlauzi, a malayitsha interviewed in Bulawayo, boasted, "I am a bank of the people. I don't want to know if you pay taxes, whether you work or how you got the money. I will simply take it to its recipients, no questions asked". 5

Below, I further this discussion of the omalayitsha by looking at the ways in which the omalayitsha themselves have come to embody regional grievances

3 Ibid.

4 Informal discussion with street vendors, Bloemfontein, South Africa, 9 November 2012.

5 Interview with Mlauzi, Bulawayo, 18 August 2011. 
in Matabeleland (and to a certain extent also symbolise resistance), before turning to discuss variation in the omalayitsha modus operandi.

\section{Narratives of the Origins of omalayitsha and Marginalisation in Matabeleland}

In Matabeleland, narratives of the origins of the malayitsha system generally start with the aftermath of the episode of state violence known as Gukurahundi. Of course, people acknowledge the much deeper cross-border ties that resulted from the nineteenth-century northward migrations of the founders of the Ndebele state, as well as the importance of colonial labour migration (detailed in Muzondidya 2010). But the idea that Matabeleland has been discriminated against post-independence, and that this explains the growth of omalayitsha is widely articulated. One of the larger registered malayitsha operators interviewed in this study - Mdawini, a former Zipra freedom fighter turned cross-border operator - lamented "while other regions of the country enjoyed the fruits of the liberation struggle, Matabeleland was displaced from Zimbabwe's development agenda". ${ }^{6}$ He elaborated:

Crossing borders is nothing spectacular. With or without passports, out grandfathers moved around before the whites came, after they came and imposed passports, they continued going to WENELA by any means and during the liberation struggle, guerrillas moved between borders as much as they wanted in spite of state restrictions. ${ }^{7}$

He continued, "What is a border anyway except a set of rules that can be bent?"8 Notwithstanding a longevity of crossing and integration over the border, the state violence of the 1980 s stands out in my narratives as the primary explanation for deepening cross-border ties after independence. During this conflict, Mugabe's ZANU(PF) government sought to eliminate Joshua Nkomo's ZAPU opposition party, and unleashed violence both against a small number of 'dissidents' who had taken up arms in the bush, and against civilians and zAPU party officials more broadly. Ethnicity was mobilised during the operation, which was widely understood as an effort to eliminate not only Zapu but also 'the Ndebele' (CCJP 1999; Alexander et al. 2000; Phimister 2008). An estimated 20,000

6 Mdawini, Greyhound bus terminal, Bulawayo, 20 July 2011.

7 Mdawini, Greyhound bus terminus, Bulawayo, 20 July 2011.

8 Ibid. 
people were killed, primarily by the North Korean trained Fifth Brigade that answered directly to Mugabe. Violence ended only with the signing of the Unity Accord in 1987. The 400,000 inhabitants of Matabeleland South were also in the grip of a severe drought at the height of state repression, and the government blocked food aid to the region (Phimister 2008). One of my respondents, Dube, recounted the origins of his migration and cross-border malayitsha business in this episode, as he described being compelled to join many others fleeing to South Africa and Botswana where he sought work to support those left behind. ${ }^{9}$ He emphasised how "they wanted to eradicate us (the Ndebele) not just politically and economically, but also ethnically as well". But he also emphasised "Zimbabwe is our home", and cast going to South Africa, and the maintenance of connections though omalayitsha as a means of 'survival and resistance.'.10

The legacy of Gukurahundi was one of disaffection on the part of Matabeleland, notwithstanding the Unity Accord of 1987, which brought an end to violence and incorporated ZAPU leaders into ZANU(PF). The episode entrenched popular understandings of longstanding dualistic antagonism between 'Ndebele' and 'Shona' and produced a sense of particularistic Ndebele grievance (Ndlovu-Gatsheni 2012). The episode heightened cross-border integration. Nqobani Dube explained that this was why: "We have a more intimate relationship with Jo'burg than we do with Harare; in fact, Jo'burg has become our capital and Harare is like a foreign city to us."11 Another respondent, Zimiso, who was studying at the University of Zimbabwe in Harare, pointed out how, although born after the Unity Accord, he had never been to Harare until he began his University studies and yet he had been to Botswana and South Africa countless times. ${ }^{12} \mathrm{He}$ explained this in terms of the fears instilled in him of the horrific stories of brutality "inflicted on our people" and elaborated "I only came to Harare because the education was cheaper than in South Africa but I hate Harare and would rather work in South Africa" (cf. Ndlovu-Gatsheni 20ogb). ${ }^{13}$ It is widely upheld within Matabeleland that there is discrimination against the region in terms of government investment in schooling, as well as other services (Ndlovu-Gatsheni 2009b; Alexander et al. 200o). Thus one of the malayitsha interviewees - Ngwenya - explained:

\footnotetext{
9 Interview with Dube, Lupane, 17 August 2011.

10 Ibid.

11 Interview with Nqobani, 18 July 2011.

12 Comment made by Zimiso on a presentation of a draft of this paper at the Economic History seminar series at the University of Zimbabwe, May, 2012;

13 Ibid; Zimiso expressed these sentiments to me after the seminar.
} 
We the people of Matabeleland, most of us really, we never got an education, let me put it this way. That's why people from Harare are coming to get good jobs here in Bulawayo. The bottom line is - we are forced to go to South Africa and Botswana. ${ }^{14}$

The omalayitsha transport and courier networks were thus seen as the product and legacy of exclusion, as well as embodying a spirit of resistance and survival. These operators did not cast themselves simply as entrepreneurs pursuing their private business interests, but rather as providing the necessary service of economic sustenance for people of the region, filling in where the government had neglected and discriminated against its citizens. This history and explanation for omalayitsha could also be upheld as a reason for circumventing state controls, which some omalayitsha viewed with contempt. The very existence and success of omalayitsh $a$ entrenched Ndebele grievances insofar as they embodied evidence of their displacement and marginalisation in Zimbabwe, which had resulted in their embeddedness in the South African context, where many had gone on to acquire citizenship. The malayitsha Tony Khumalo explained how he acquired South Africa papers himself informally in the 1990s: "We had to be organised among ourselves as amaNdebele so that we were able to send money, groceries and furniture home. It was after realising that I could make money from providing this service that I started this business. I initially operated with clients from my home area until I expanded my business years later."15 Although Zimbabwean law came to require migrants such as Khumalo to revoke their Zimbabwean citizenship, most did not do so. Indeed, as will become clear below, many of the more successful early malayitsha businesses that originated in the aftermath of Gukurahundi were started up by people who had papers in South Africa.

The omalayitsha themselves provided narratives of cross-border business in general and their own entry into it that hinged centrally on Matabeleland's history of labour migration, combined with post-independence marginalisation. For Ngwenya, "this system started way back with our grandparents going to WENELA. Today, the migration is determined by education levels and most Ndebele go there because they do not have as much education as the Shona". ${ }^{16}$

The dramatic expansion of cross-border courier business from 2000 was upheld as evidence of governmental mismanagement of the economy.

\footnotetext{
14 Interview with Ngwenya. Bulawayo 18 August, 2011.

15 Interview with Khumalo. Bulawayo, 19 August, 2011.

16 Interview with Ngwenya, Bulawayo, 18 August 2011.
} 
Mdawini stated, "What would you be wanting in South Africa if everything is there back home? It is this mal-administration that creates business for us". ${ }^{17} \mathrm{He}$ argued, "Our people are suffering in South Africa. Their accommodation is poor as compared to here. Zimbabwe is much better; however, people resort to going because they just have no option and can't stay at home". ${ }^{18}$ Although Matabeleland post-independence history was specific and fuelled particularistic understandings of persecution in Matabeleland, the recent crisis generalised suffering and exodus. To some extent, 'tribal' tensions created by Gukurahundi were diluted by a sense of solidarity against ZANU(PF), as evidenced by the support the region gave to the new nationwide opposition Movement for Democratic Change in the 2000 and 2002 elections. Matabeleland politics thereafter has been fractious and complex as the MDC split in 2005 and the smaller grouping had a regional/ethnic constituency in Matabeleland. Ndebele nationalist parties have also taken a small part of Matabeleland's vote, such as the revived ZAPU and more recently Mthwakazi (Ndlovu-Gatsheni 2012). While it is clear from the above that the growth of malayitsh a business is intimately connected to a longevity of cross-border migration and specific regional histories of violence, displacement and disaffection, it is also necessary to distinguish between different types of business. The shared narrative of origins and common understanding within Matabeleland of regional neglect masks the considerable variation between the large registered operations and the smaller operators widely seen as 'poachers' and 'criminals'.

\section{A Typology of malayitsha Business}

Cross-border couriers range from large formally registered consortia of crossborder transport businesses, to small informal businesses run by individuals who possess a vehicle. ${ }^{19}$ Here, I will develop a three-fold categorisation, exploring different modes of operation, varying relations with the Zimbabwe and South African state authorities, and with customers. I detail how these businesses developed over time: how the trajectories of individual businesses were linked to the dynamics of the crisis period, becoming the primary means through which migrants within the region sent money and goods back home. The formal/informal distinction does not map neatly onto businesses of differ-

\footnotetext{
17 Interview with Mdawini, Greyhound bus terminus, Bulawayo, 17 August 2011.

18 Ibid.

19 See section 1 (a) for a range of remitting options.
} 
ent size, as the nature of the crisis in Zimbabwe and the changing character of transport regulation meant that even large formal companies were operating partly irregularly.

\section{Large Registered Courier Companies}

The largest omalayitsha businesses comprise some of the country's major transport companies plus associations of small business people who have come together in registered co-operatives. They have all followed the Ministry of Transport's cumbersome process of licensing and getting permits, and maintained vehicle, passenger and goods insurance. Regular vehicle inspection and fitness tests were an essential part of the process. The companies interviewed include Dube Tours, Lance Transport and the Zimbabwe Long Distance Van Line Transport Association (ZLDVLTA), which is a consortium of businesses. These firms typically run sizeable fleets of buses, minibuses (known as 'kombis') and pick-up trucks (known as 'bakkies'), and are well established with good reputations for transporting people and providing courier services. Some are also involved in long-distance haulage, but here I focus primarily on their role as couriers and conduits for remittances. The ZLDVLTA partners with a South African equivalent association called the South African Long Distance Van Line Transport Association (SALDVLTA) which, interestingly, is dominated by South Africans of Zimbabwean origin. One registered operator within the ZLDVLTA, Sikhosana, indicated how, in spite of the challenges associated with formalising their business, "At least you have less police intrusion on your back. The papers can cover you, and it indeed protects our members, some of whom might want to use that cover to smuggle contraband but we have a strict and punitive policy against such activities." 20 Among these registered operators, some had expanded beyond Matabeleland, operating nationwide or regionally including in neighbouring countries such as Malawi and Zambia. Dube the owner of Dube Transport and member of ZLDVLTA - likewise argued that such formal associations were established with the vision of enforcing certain codes of conduct. ${ }^{21}$ Interestingly, some of the companies and vehicles in the large operator category were not registered primarily in Zimbabwe but in South Africa, and were run by Zimbabweans with South African citizenship. To register and gain permits to operate in Zimbabwe, they needed to show a South African Revenue Service (SARs) certificate. ${ }^{22}$

\footnotetext{
20 Interview with Sikhosana, Bulawayo, 17 August 2011.

21 Interview with Dube, Lupane, 17 August 2011.

22 Ibid.
} 
The directors of these large companies started off from very humble origins. One director, Lance Ngwenya, for example, started off in 2002 with two Peugeot 504 super 7 vehicles, moved to a Toyota venture ( 7 seater), then minibuses or taxies and eventually acquired a larger fleet with his partner. ${ }^{23}$ The fleet now includes Toyota Hiace taxis, Toyota Quantums, and single and double cab Toyota bakkies all operating from a warehouse. Ngwenya noted how the lack of business opportunities within Matabeleland led him to get involved in this lucrative cross-border courier business. ${ }^{24}$ As the crisis deepened, Ngwenya noted, so did his fortunes increase, especially around 2008 , at the height of the crisis. In his view, "the shortages, the financial crisis and the mass emigration of people were our Chiadzwa [diamond fields].” The more recent economic stability after 'dollarisation' [i.e. the withdrawal of the Zimbabwe Dollar] had not totally undermined business, but it had 'put a dent in profits - GNU [the Government of National Unity] and dollarisation stabilised things and business slowed down. ${ }^{25}$ There was still a residual, regular by-weekly cross-border business for his company: "There is no significant recovery in the economy. Many are still out of work and while goods are still in the shops, the major source of household survival still remains the supplies and money from our Wednesday to Sunday boys veMzansi [from the south]."26

Another formal operator, Mdawini started off in 1996 after taking over from his brother who had emigrated to the United Kingdom (UK). Mdawini acknowledged that in the late 199os, the business was rescued from collapse by remittances from this brother. However, the period after 2002 saw the business becoming more sustainable "to the extent of taking a life of its own and even financially bailing out my brother in the UK at one point". Over the course of the crisis, he expanded business notably, securing major governmental and large corporate contracts. The collapse of the Zimbabwean railway service was particularly important for road-based transporters, and goods that would have previously been carried by train now were carried by truck. Mdawini had political connections, and acquired a ranch through land reforms in 2007, appreciating ZANU(PF)'s doctrine of indigenisation. The GPA and dollarisation "reduced the volume of business but failed to eliminate us." ${ }^{27}$ Sikhosana, a partner of Mdawini, noted how "even some corporates were seeking our services; we are now cheaper and more efficient than the defunct Clan [a large corporate player

23 Interview with Ngwenya, Bulawayo, 18 August 2011.

24 Ibid.

25 Interview with Ngwenya, Bulawayo, 18 August 2011.

26 Ibid.

27 Ibid. 
who ceased operations in Zimbabwe]. We would charge between 30 to $40 \%$ to buy on behalf of the companies or pick up their orders." ${ }^{28}$ These large contracts had not ended with dollarisation. Sikhosana elaborated, "we are still actually transporting bearings to a mining company in Marange on behalf of a company called B\&E International." ${ }^{29}$ Despite these big contracts, the company had not deserted its original business of supplying remittances to households. While the initial locus of their operations was Matabeleland, they had exploited broader economic opportunities beyond Matabeleland as these presented themselves as the crisis deepened.

South African citizenship and the access to credit it provided was of great benefit to many of the large malayitsha businesses. Ngwenya, Mdawini and Sikhosana are examples of operators who initially acquired vehicles financed by loans in South Africa at concessionary rates. In Zimbabwe, the financial system collapsed, and the disappearance of regulated credit posed a particular problem for those wanting to start up businesses, whose only option was to turn to 'loan sharks'. ${ }^{30}$ Because of the huge profits made from the malayitsha business during the crisis, many formal operators with South African registered vehicles managed to quickly work off the South African loans allowing them to raise the finance for further expansion of their fleet. Mdawini noted how at some point his company even managed to acquire a new vehicle without having to seek bank finance for it. ${ }^{31}$ After $2-5$ years, the vehicle had handsomely paid itself off and could easily be sold in Zimbabwe at a high price, after being brought in by the owner as a returning resident (who does not have to pay duty). Vehicle prices were very high in Zimbabwe because of duties amounting to as much as $80-100 \%$ of the original purchase price. Huge profits were thus realised from either smuggled vehicles or those brought in by 'returning' Zimbabwe residents. ${ }^{32}$ Ngwenya joked, "I am a citizen of the greenback. While I am proudly Ndebele, I can also be proudly South African, or proudly Zimbabwean, even proudly Somali if it suits me!"33

Returning residents who had in the interim acquired South African papers manipulated the fiscal loopholes to their benefit. In other instances, an old courier vehicle would get a temporary import permit and be sold without duty

\footnotetext{
28 Interview with Sikhosana, Bulawayo, 18 August 2011.

29 Ibid.

3o The three respondents confirmed this situation.

31 Interview with Mdawini, Greyhound bus terminus, Bulawayo, 20 July 2011.

32 Interview with John, zIMRA, Beitbridge, 26 May 2012.

33 Interview with Ngwenya, Bulawayo, 2o July 2011.
} 
payments. ${ }^{34}$ Some vehicles were thus imported, sold off and the money used in South Africa as down payment for a newer vehicle. Having South African citizenship was, therefore, perceived as an opportunity for profit in addition to enabling the provision of a much needed cross-border courier service.

According to Ngwenya's vivid description, "our service is actually very convenient. Imagine you want to send something home, but you can't board a bus and pay R300 and then pay R400 or so for luggage. Return transport is another R30o and so just to ferry your goods home, you will have spent over R1,00o." Maphosa observed that attempts to avoid such costs explain the huge surge in malayitsha business. Ngwenya noted how his own $20 \%$ charges were a 'mere token'. Nonetheless, these 'tokens' were cumulatively very lucrative. According to Ngwenya, "nowadays, a single trip can earn the transporter roughly R7,0oo after overheads." 35

The respondents from these large, registered cross-border transport services reported relatively good relations and few challenges with the authorities such as the Zimbabwe Revenue Authority (ZIMRA) or the police. A zIMRA official called John echoed testimonies from other ZIMRA and police officers I had informal discussions with, noting how they rarely detected illicit activities with these registered operators as they were licensed, paid import revenue, were insured and 'cut less corners compared to mapoacher [poachers]. ${ }^{36}$ Nonetheless, "in our job," he said, "we will always find something wrong if we look hard enough. Anyway, let's just say that these established guys know the rules of the game so they are easier to work with than the tsotsies [criminals] just starting."

These claims to legal practice were, however, disputed by the rivals of the large operators, the smaller 'poacher' malayitsha operators, who were sceptical, given the impossibility of doing legal business over the course of the crisis. The latter also cast the large operators as ruling party supporters, whose relationship with the authorities allowed them to get away with breaking the rules. One such, a Kombi driver, argued that the large firms used their formal registration and privileged financial position to smuggle more things than the average small player and had some officials "in their pockets" ${ }^{37} \mathrm{He}$ continued, "otherwise, how on earth would they have survived the crisis?" Indeed, while the formal registered omalayitsha were protected by their registration and relations with

Such vehicles were called zvidhuura or ghost cars as they are not registered or licensed. It is said that such cars could be used for robberies and illicit activities as they were not easy to trace. Interview with police officer Nikita, Beitbridge, 26 May 2011.

36 Interview with John, zIMRA official, Beitbridge, 26 May 2012.

37 Interview with 'poacher' driver, Max Garage, Bulawayo, 20 August 2011. 
state officials, the hyperinflation and political economy had reduced everybody to seeking irregular ways to 'make do' (Jones 2010). They would kiya-kiya [makedo] through avoiding duties, smuggling goods, and machine and vehicle spare parts, and there have been press headlines accusing them of people trafficking, among other things. ${ }^{38}$ The unregulated side businesses that were particularly common were currency trading, exchanging money customers gave them in South Africa and avoiding the punitive state official rates, in the name of assisting clients. Indeed this was standard practice among large cross-border businesses during the hyperinflationary period from 2006.

Many of the large registered operators had started out as informal operators, which is how they accumulated finance to register formal businesses. They felt aggrieved that there was no official clampdown on the informal competition; they were getting a raw deal because they had paid for licences to operate and asserted that they had the right to be protected from unlawful operators. There was competition and mutual acrimony between the formal and informal 'poacher' operators, and the latter parked directly outside the zLDVLTA offices. The discussion now turns to these smaller 'poacher' operations, starting with medium sized businesses, whose businesses did follow at least some of the rules.

\section{Medium Size Operators of Commuter Taxis and Kombis}

Medium sized malayitsha businesses doubled as operators of commuter taxis/ kombis within Bulawayo. These included drivers among the consortia referred to above, only some of whom drove their own vehicles, while others were mere drivers for vehicles belonging to 'bosses'. In general, these medium sized operators were not as well off or as well connected as the first group. Some had valid commuter permits, but these were not always renewed and they did not stick to their stipulated routes, preferring to chase the money, even if it meant doing what was not allowed by the permits. Those who were not themselves members of registered associations, could also be counted among the 'poachers'. They sometimes formed their own loose and informal associations. The 'poacher' driver thus argued that although they all wanted to be registered, there were huge challenges to doing so. ${ }^{39}$

The medium sized unregulated operators that I interviewed seemed to embrace the label of 'poacher', adopting it however, with a completely different meaning that validated independence from $\mathrm{ZANU}(\mathrm{PF})$ and state authorities.

$38 \quad$ Ibid.

39 Ibid. 
According to one 'poacher', Mpilo, 'the associations are simply groups of people who are benefiting and are being protected because they are ZANU(PF) supporters. ${ }^{\prime 4}$ This accusation not only captured the rivalry between registered operators and 'poachers', but showed how the smaller players viewed the bigger players as privileged financially by virtue of connection to a regime they denigrated as itself corrupt. Indeed, the medium operators saw the regulated operators as the biggest poachers in the game, benefiting from state largesse, free premises and protection. ${ }^{41}$ According to one 'poacher' driver, "while they [the big operators] use premises provided by the government, who is going to represent us?" $42 \mathrm{He}$ then went on to validate the importance of 'levelling the playing field' by poaching the clients of the bigger companies.

While most 'poacher' operators flouted transport and courier operational regulations for permits, licensing, and insurance for passengers and goods, they argued that their services were desired by clients for numerous reasons, primarily cheaper cost. According to Mpilo, "we tend to be cheaper as we are not obliged to pay any dues to an association. Also, we don't have regulated times of operation; we simply fill the car and depart, and as such we are fast and convenient." 43 Of course, while subscriptions and licensing increased the costs of formal associations, the kombi drivers still needed to pay touts that came to be known as 'rank marshals', referred to colloquially as 'mahwindi'. The term mahwindi refers to being in the wind, initially associated with conductors who jumped onto moving kombis and suspended themselves in the wind. Taxi ranks were supposed to be designated by the city council but because "poachers would not have access to the formal ones, they created their own." ${ }^{44}$ This would be done through 'negotiations' with local authorities on the part of a prominent rank marshal to allow their 'members' to operate at an undesignated site. ${ }^{45} \mathrm{As}$ such, 'cherenki' [protection money] had to be paid to mahwindi to the order of the fare of one passenger, a significant portion of which was handed over to the senior mahwindi patron. Other costs the poacher operators had to meet included bribes paid to the police along the highways. ${ }^{46}$

The small to medium scale transporters generally appear to hold Zimbabwean citizenship and thus lack access to the financial services available in

\footnotetext{
40 Interview with Mpilo, Max garage, Bulawayo, 18 August, 2011.

41 Ibid.

42 Interview with 'poacher' driver, Max garage, Bulawayo, 20 august 2011.

43 Interview with Mpilo. Max garage, Bulawayo, 18 August, 2011.

44 Ibid.

45 Interview with Muvet, Max garage, Bulawayo, 20 August, 2011.

46 Interview with 'poacher' driver, Max garage, Bulwayo, 20 August, 2011.
} 
South Africa. While the privileges that came with South African papers were held with contempt by the small to medium operators, some of those I interviewed admitted that they were actually working towards acquiring such a status for the rewards it promised. ${ }^{47}$ While these medium operators posed stiff competition to the registered players and plied their routes daily, their overheads tended to be high, with funds lost in bribes to traffic police and zIMRA officials. They also tended to transport relatively bulky less profitable cargo. ${ }^{48}$ Old and unreliable vehicles meant that they could not attract larger contracts. ${ }^{49}$ While the formal players tended to separate and differentiate transport and courier businesses, the smaller players tended to double transport of people with that of their cargo.

These medium operators sometimes managed to rise into a large, registered company, particularly where partnerships and pooled capital had allowed them to increase the scale of operations. There were thus advantages of working within the umbrella of an association, even though they still competed among themselves, which distinguished their business from the poorer financed, illorganized small operators to which I turn next.

\section{Small Operators}

The third group of omalayitsha comprised new entrants, operators who were not well connected, as well as those whose businesses were in decline. In most cases, these were independent omalayitsh a running a single pick-up truck or a kombi, and many were acting as omalayitsha only part-time, using this business to supplement other incomes. They were undercapitalised and used comparatively older vehicles. Their clientele tended to be close associates, former workmates, schoolmates, friends and close relatives. ${ }^{50}$ According to interviews, the majority of these emerged in the post-2002 period. ${ }^{51}$ Typically, the newer entrants were relatively young, and some had started up independently by breaking away from other omalayitsha whom they worked for. It was this category of malayitsha that included the stereotypical 'poachers', accused of swindling the unsuspecting, and getting away with it as they were difficult to

\footnotetext{
47 Interview with 'poacher' driver, 20 August, 2011; and with Mpilo, both held at Max garage, Bulawayo 18 August, 2011.

48 Interview with Khumalo, Pumula, Bulawayo, 20 August 2011.

49 Ibid.

5o Interview with Khumalo, Pumula, Bulawayo, 20 August 2011.

51 Interview, Barney, Bulawayo, 17 December 2011; Interview with Jussy Nketa 8, Bulawayo, 17 December 2011; interview with Khumalo, Pumula, Bulawayo, 20 August 2011.
} 
trace. ${ }^{52}$ One 'poacher' driver noted that he charged between R300 and R500 for returning a Zimbabwean without documents across the border. They were also difficult to interview, as most declined to talk. Those I did manage to speak to came from different backgrounds. Some were educated and had held formal sector white collar jobs (one, Jussy had a degree in Business Studies from the University of Zimbabwe (Uz) and was a former bank employee of one of Bulawayo's major banks; another, Khumalo, was a retired teacher with a bottle store who had a small pick-up truck and used it for malayitsha business on occasion). Another 'poacher' business discussed below had been set up by a group of four former rank marshals/conductors in Magwegwe suburb of Bulawayo who had pooled resources to buy one kombi between them, and finally there were a group of young men from Bulawayo who were foot couriers in the border towns of Plumtree and Beitbridge and lacked their own vehicle.

The Uz graduate, Jussy, was 27 years old. He had enjoyed his job in the bank, but his salary was eroded by inflation and he became frustrated and decided to resign. ${ }^{53}$ Unlike some of his colleagues, who made small fortunes through 'burning' money [i.e. by exploiting differences between official/unofficial rates, interbank transfer and other means] and had contacts in the Bualwayo street currency markets (see Mawowa and Matongo 2010) he was not well connected. When he was still working, he bought a kombi and used it to run part-time courier services to Botswana. Gradually, he realised that he was making more from his weekend courier business than he was from full-time employment. It "was far more lucrative than actual employment. That's why in 2007, I resigned my job and decided to do this full-time." 54 While this paid off from 2007 to 2008 , after dollarisation in 2009, the demand for groceries from Botswana shrank and, according to Jussy, "it no longer pays as much and I need to go back to work. This is worsened by the fact that I have to buy parts and can't afford to buy another vehicle." ${ }^{55}$

The group of former mahwindi from Magwegwe who had pooled resources to buy their second-hand kombi were initially highly suspicious of me, though over time, they warmed up and we were able to have informal discussions. ${ }^{56}$

$5^{2}$ Interview with Norman Taruvinga, Cowdrie Park, Bulawayo, 17 December 2011. He was swindled by a young malayitsha who was supposed to deliver money from his cousin in South Africa. The cousin handed over R1,50o but never saw the young man again.

53 Interview with Jussy Nketa 8, Bulawayo, 17 December 2011.

54 Ibid.

55 Ibid.

$5^{6}$ Interview/discussion with mahwindi conducted by Brian Kauma, Magwegwe Bulawayo 19 December 2011. 
They took turns to drive the kombi, which they operated as both a commuter service and malayitsha. ${ }^{57}$ They were open about how they would assist people without travel documents to cross the border. Indeed, they thought, "there is nothing special about this because even the major bus companies do this. It is an open secret to everyone, including the police and the government itself. But if we do it, we are labelled tsotsies [criminals]."58 They said they would smuggle anything that brought them money. One described using friends at the border whom he had met initially through an Indian businessman. He regularly used these contacts to 'jump' the border and avoid paying duties for the same Indian businessman's car. ${ }^{59}$ Another boasted that he could easily drive a stolen car across the border. It appeared to me that for this group, there was more to their union than simply malayitsha business. ${ }^{60}$ Indeed, what they said about their business seemed to fulfil the image of criminality that the large registered operators had of them. They would be accused of the type of incident that was recounted to me of a malayitsha who had abandoned his passengers in Cowdrie Park after receiving payment in the form of heads of cattle for his passengers' safe passage to South Africa: he had disappeared without meeting his end of the contract, and was being hunted down by the police. ${ }^{61}$

I collected many stories of small-scale omalayitsha of the type that appear in the press: of dangerous human traffickers who prey on desperate people, extorting sexual favours or selling off desperate female migrants into prostitution rings. ${ }^{62}$ I was told that male migrants are sold off to employers to work off debts owed to omalayitsha, and that some omalayitsha 'unilaterally volunteer intimacy' on behalf of the sending husbands to the recipient wives. ${ }^{63}$ During my visit to Lupane, there was a story circulating about a returning migrant worker who murdered his wife upon learning of an affair she had had with a malayitsha he had often used to remit. ${ }^{64}$ But, the groups of former mahwindi turned malayitsha defended their reputation. They pointed to the fact that

\footnotetext{
$57 \quad$ Ibid.

$5^{8}$ One of the mahwindi, who appeared to be the older and most senior among them, kept repeating this point.

59 Ibid.

60 Ibid.

61 Interview with Norman Taruvinga of Cowdrie Park, Bulawayo, 17 December, 2011.

62 Interview with Norman Taruvinga, cf interview with Shadreck Svikiro, Cowdrie Park, Bulawayo; Ernest Jackson, Bulawayo, 17 December, 2011.

63 Interview with Barney, City Centre, Bulawayo, 17 December 2011.

64 Interview with Mtolisi, Lupane, Bulawayo, 17 December, 2011.
} 
clients themselves are not always honest. ${ }^{65}$ According to Dube, there are cases where 'pay forwards' are not always honoured, for example. ${ }^{66}$ The 'pay forward' system involves situations where relatives can 'post' loved ones to destinations, but in some cases, the transporters do not receive their payment.

Their business seemed rather different than that of the retired headmaster, Khumalo, who had an old 1991 Isuzu pick-up truck and ran a bottle store and grocery business. He seemed far removed from the opportunistic and potentially violent world of the groups of young men. While he struggled with his business, his son sometimes helped out, driving his pick-up truck which doubled as a delivery car and a courier vehicle. ${ }^{67} \mathrm{He}$ was sometimes paid commission for the internal transportation of goods and delivery of money that had been brought in from South Africa by his friend who was a full-time malayitsha but who was not prepared to transport his cargo to rural areas. Sometimes, the son would drive the vehicle for contracts in South Africa but given the condition of the car, it was being used more for local deliveries. ${ }^{68}$

The last group of poacher omalayitsha were the borderland foot couriers. Those I spoke to were young and unemployed youths who had moved from Bulawayo to the border town of Beitbridge. ${ }^{69}$ Some who carry on foot also had access to vehicles, but those I spoke to worked only on foot, though they aspired to be omalayitsha proper, i.e. to have their own pick-up. They were called magumaguma because of their relatively low charges. While this group also had the worst reputation for people trafficking and varieties of fiscal and violent crime, they arguably also worked particularly hard, walking for many kilometres carrying their customers' goods and acting as escorts. Their only investment was their labour power and normally made enough to subsist themselves but struggled to look after their families. ${ }^{70}$

\section{Dollarisation and Power Sharing}

The typology presented above has begun to illustrate how the withdrawal of the Zimbabwe dollar and power-sharing in 2009 affected business. One important

\footnotetext{
65 Interview with mahwindi. Magwegwe, Bulawayo, 19 December, 2011.

66 Interview with Dube, Lupane, 17 August 2011.

67 Interview with Khumalo. Pumula, 20 August, 2011.

68 Ibid.

69 Interview with Dingiswayo, Dulibadzimu township, Beitbridge, 25 May 2012.

70 Interview with Dingiswayo and from a discussion with 8 of the magumaguma, 26 May 2012.
} 
factor was the removal of visa requirements by the South African government in 2007 and the granting of temporary residence status to illegal Zimbabwean migrants resident in South Africa. Though many illegal migrants did not get official permits, their circumstances ameliorated somewhat. Following dollarisation in 2009, the cost of acquiring a passport was lowered to US $\$ 50$ which took no longer than three months to be issued, making the exercise more affordable. Secondly, the unity government between ZANU(PF) and the two MDC parties in 2009 stimulated many changes to the political and economic landscape of Zimbabwe. The most important economic change was the official adoption of the multi-currency system dominated by the us dollar and South African rand. This had the effect of arresting hyperinflation and stabilising the economy. These developments along with the hope brought by including the MDC parties as part of the government also increased business confidence to some degree. Moreover, the availability of basic commodities at comparatively stable prices reduced the need to send omalayitsha to South Africa or Botswana to buy things or the need of those in South Africa to remit the same. ${ }^{71}$

Nonetheless, the problems are still substantial. While most omalayitsha admit that the volume of their business has decreased, they note that they still get enough business to make a 'reasonable' profit. ${ }^{72}$ The Zimbabwean economy has not improved to the point of creating enough sustainable jobs for its citizens and it remains dominated by South African manufacturers creating a situation where dependency on South Africa is still significant. As such, the drift towards South Africa continues. The lack of visa requirements for work made it much easier for illegal migrants to find their way across the border using their passport to gain entry and then simply overstay, if not just disappear. ${ }^{73}$

\section{Conclusion}

This article used the case of Matabeleland's cross-border malayitsha couriers - who are the main means through which migrants send money and goods home - to contribute to broader debates over remittances. Firstly, it argued that the literature should pay more attention to the courier and transport businesses

71 Interview with Barney, City Centre, Bulawayo, 17 December, 2011.

72 Mdawini, Ngwenya, Dube, Sikhosana, the mahwindi, 'poacher' drivers all agreed on this point. However, smaller, newer players such as Barney and Jussy struggled to remain afloat after 2009.

73 Interview with Mdawini, greyhound bus terminus, Bulawayo, 20 July, 2011. 
themselves, which are generally ignored in the literature. This omission is surprising and important given the importance of courier businesses as channels for remittances. The three-fold typology of operators I have developed - large registered companies, medium-scale independent operators and small-scale 'poacher' operators - highlights the diversity of forms and modes of operation that these cross-border transport businesses take. I hope to have shown that popular discourse which casts the large operators as 'formal' and the small businesses as 'informal' or 'criminal', is misleading in some ways, as the contours of irregularity are less stark and relations with the state more complex. Indeed, notwithstanding the omalayitsha's shared articulations of Matabeleland grievances, some of the larger businesses had close relations with the state. Such individuals show the legacies of the1987 Unity accord that followed Gukurahundi, through which ZAPU was brought into ZANU(PF) and created a very small Matabeleland gerontocracy, which continues to decrease in size, as Matabeleland has become overwhelmingly disaffected.

Secondly, the article called for studies of remittances to move beyond the national scale and to explore specific regional economies and histories that give meaning and wider significance to some cross-border transport systems. The malayitsha cross-border business operators are widely upheld as symbols of Matabeleland's neglect, as living evidence of the lack of state investment in education for the people of Matabeleland, as a legacy of the violent conflict that caused displacement across the South African border in the early 1980 s. As such they disrupt the timeline of emigration associated with the more recent generalised trajectory of economic decline associated with the recent 'crisis'. The scale and importance of the omalayitsha cross-border courier business thus provide continual tangible reminders of particular Matabeleland histories of displacement and grievance.

\section{References}

Alexander, Jocelyn, JoAnn McGregor, and Terence Ranger. 2000. Violence and memory: One hundred years in the 'dark forests' of Matabeleland, Zimbabwe. Oxford: Heinemann and James Currey.

Bracking, Sarah, and Lloyd Sachikonye. 2010. 'Remittances, informalisation and dispossession in Urban Zimbabwe'. In: Jonathan Crush and DanTevera (eds), Zimbabwe's exodus, crisis, migration, survival. Cape Town: SAMP. 324-345.

CCJP. 1999. Breaking the silence-building true peace: A report on the disturbances in Matabeleland and the Midlands, 1980-1988. Harare: The Legal Resources Foundation. 
Crush, Jonathan, and Dan Tevera. 2010. Zimbabwe's exodus, crisis, migration, survival. Kingston and Cape Town: SAMP.

Dorman, Sara Rich. 2005. 'Make sure they count nicely this time': The politics of elections and election observing in Zimbabwe. Commonwealth and comparative politics, 43 (2):155-177.

Gono, Gideon. 2008. Zimbabwe's casino economy: Extraordinary measures for extraordinary challenges. Harare: ZPH Publishers.

Jones, Jeremy L. 2010. 'Nothing is straight in Zimbabwe': The rise of the Kukiya-kiya economy 2000-2008. Journal of Southern African Studies, 36 (2):285-299.

Kriger, Norma. 2010. 'The politics of legal status for Zimbabweans in South Africa'. In: JoAnn McGregor and Ranka Primorac (eds), Zimbabwe's new diaspora: displacement and the cultural politics of survival. New York: Berghahn Books. 77-100.

Maphosa, France. 2005. 'The impact of remittances from Zimbabweans working in South Africa on rural livelihoods in the southern districts of Zimbabwe'. In: Forced Migration Working Paper 14. Johannesburg: Wits University.

Mawowa, Showers, and Alois Matongo. 2010. Inside Zimbabwe's roadside currency trade: the 'World Bank' of Bulawayo. Journal of Southern African Studies, 36 (2):319337 .

McGregor, JoAnn, and Ranka Primorac. 2010. Zimbabwe's new diaspora. Displacement and the cultural politics of survival. New York: Berghahn Books.

Mutowo, Maurice. 2009. The flow, impact and regulatory rramework for migrant labour remittances. Harare: Labour and Economic Research Institute of Zimbabwe.

Muzondidya, James. 2010. 'Makwerekwere: Migration, citizenship and identity among Zimbabweans in South Africa'. In: JoAnn McGregor and Ranka Primorac (eds), Zimbabwe's new Diaspora: Displacement and the cultural Politics of Survival. New York: Berghahn Books. 37-58.

Ndlovu-Gatsheni, J. Sabelo. 2012. 'Professor Gatsheni's rendition on Mthwakazi's colourful history'. In: Agenda4Action: uMthwakazi Review, www.umthwakazireview .com.

Ndlovu-Gatsheni, Sabelo J. 2009a. Do 'Zimbabweans' exist?: trajectories of nationalism, national identity formation and crisis in a postcolonial state. Oxford: PIA publishers.

Ndlovu-Gatsheni, Sabelo J. 20ogb. The Ndebele nation: Reflections on hegemony, memory and historiography: UNISA Press.

Peacock, Brendan, 2013. African migrants pay the price in remittances. Africa Business Day Live, 10 March 2013, http://www.bdlive.co.za/, retrieved 21 May 2014.

Phimister, Ian. 2008. The making and meanings of the massacres in Matabeleland. Development Dialogue, 50:197-214.

Roitman, Janet Lee. 2005. Fiscal disobedience: an anthropology of economic regulation in Central Africa. Princeton: Princeton University Press. 
SPT. 2009. 'Gone to Egoli': Economic survival strategies in Matabeleland: A preliminary study. Solidarity Peace Trust.

Vargas-Lundius, Rosemary, Marcela Villareal, Guillaume Lanly, and Martha Osorio. 2008. International migration, remittances and rural development. International Fund for Agricultural Development (IFAD) and Food and Agricultural Organisation (FAO). 